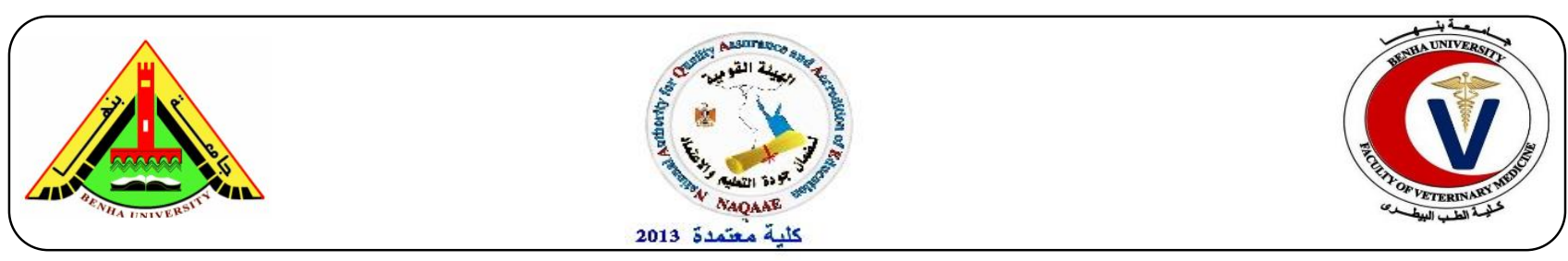

\title{
Moringa olifera Attenuated Nitrosodiethylamine-Induced Hepatocarcinogenesis by Modulating the Metabolic Activation and Detoxification Enzymes
}

Samy A. Hussein, Samir A. Abdel-Aal and Hossam A. Mady

Department of Biochemistry, Faculty of Veterinary Medicine, Benha University

\section{A B S T R A C T}

Moringa olifera was shown to exert anti-inflammatory, antioxidant, hepatoprotective properties, and anticancer activity. This study was done to investigate the protective effects of moringa olifera on Diethylnitrosamine (DEN) induced Hepatocellular carcinoma in rats. Fourty five male albino rats were divided into three groups. Group (normal control group): rats administered distilled water only. Group II: rats received diethylnitrosoamine (200 $\mathrm{mg} / \mathrm{kg} \mathrm{b.wt} / \mathrm{i} . \mathrm{p})$, two weeks later rats received ( $2 \mathrm{ml} / \mathrm{kg} \mathrm{b.wt)} \mathrm{Carbon} \mathrm{tetrachloride} \mathrm{(CCl4)} \mathrm{orally} \mathrm{at} \mathrm{1:1} \mathrm{dilution} \mathrm{in} \mathrm{corn} \mathrm{oil} \mathrm{as} \mathrm{a} \mathrm{promoter}$ of carcinogenic effect. DEN and $\mathrm{CCl} 4$ injections were repeated once again after 1 month from first DEN injection. Group III: rats received DEN then treated with moringa at a dose level of (500 $\mathrm{mg} / \mathrm{kg} \mathrm{b.wt/orally)} \mathrm{dissolved} \mathrm{in} \mathrm{distilled} \mathrm{water} \mathrm{for} 6$ weeks. All animals were sacrificed after the end of experiment. DEN induced HCC showed significant increase in hepatic marker enzymes (ALT and ALP), total bilirubin and alpha fetoprotein (AFP) with marked decrease in serum albumin concentration. Also, the results of molecular analysis of liver tissue revealed significant upregulation in TNF- $\alpha$ gene expression level. Conversely, down-regulation in tumor suppressor gene p53 and Cyp2E1 gene expression compared with control group. Treatment with moringa olifera to DEN induced HCC protects the liver cells from damage by regulating the biochemical parameters. These findings suggest the potential efficacy of moringa as an additional chemopreventive agent in treatment of hepatocellular carcionoma via initiation of tumor suppressor gene (P53) and modulating the metabolic activation of detoxification Enzyme (cytochrome P450 2E1) and antiinflammatory effect.

Keywords: Diethylnitrosamine, HCC, Moringa oliefera, P53, cytochrome P450 2 E1.

(http://www.bvmj.bu.edu.eg) (BVMJ-35(2): 638-649, 2018)

\section{INTRODUCTION}

Hepatocellular carcinoma (HCC) is a malignant neoplasm of hepatocytes and constitutes more than $80 \%$ of primary malignant liver neoplasms (Satir, 2007). Worldwide, liver cancer is the fifth most common malignancy and the third most common cause of cancer death (Kung et al., 2010).
The major avoidable causes of cancer are smoking, dietary imbalances, chronic infections and hormonal factors which are influenced primarily by lifestyle, other causal factors in human cancer are excessive sun exposure, viruses (such as human papilloma virus and cervical cancer) and pharmaceuticals (such as phenacetin, some 
chemotherapy agents, diethylstilbestrol, and estrogen) (Gold et al., 2002). Many hepatocarcinogens such as aflatoxins, acetylaminofluorene3 and diethylnitrosamine have been successfully used to develop hepatocarcinogenesis in animals (Mukherjee et al., 2009). Diethyl nitrosamine (DEN) is a potent hepatocarcinogenic nitrosamine, present in cheddar cheese, cured and fried meals, alcoholic beverages, cosmetics, agricultural chemicals and pharmaceutical agents, ground water having high level of nitrate (Mahmoud and Abdul-Hamid, 2012).

Carbon tetrachloride (CCl4) is classified as a possible human carcinogen based on inadequate evidence of carcinogenicity in humans but sufficient evidence in animals. However, there are major deficiencies in the available cancer studies. Animal studies suggest that the carcinogenicity of carbon tetrachloride is secondary to its hepatotoxic effects, indicating a possible threshold (Provincial, 2010).

A number of modern drugs have been isolated from natural sources and many of these isolations were based on the uses of the agents in traditional medicine. Moringa oleifera leaves have been found to have the same powerful antioxidant agents such as vitamins $\mathrm{C}, \mathrm{E}$ and $\mathrm{A}$ in oranges, pomegranates and carrots, as well as caffeoylquinic acids, carotenoids (i.e., lutein and a- and bcarotene), kaempferol, quercetin and rutin (Smolin and Grosvenor, 2007). Moringa oleifera oil and its micronutrients exhibit antitumor, antioxidant, antiepileptic, antidiuretic, anti-inflammatory, hepatoprotective and antidiabetic properties (Sreelatha and Padma, 2010). The present study was to investigate the chemopreventive, antiinflammatory, apoptotic and detoxification effects of moringa olifera on DEN and $\mathrm{CCl} 4$ induced- hepatocellular carcinoma in rats through evaluation of some serum liver biomarkers and molecular analysis of CYP
2E1, P53 and TNF- $\alpha$ gene expression in hepatic tissues.

\section{Materials and methods}

\subsection{Experimental animals:}

Forty-five white male albino rats of 6- 8 weeks old and weighing 150 - $180 \mathrm{~g}$ housed in separated metal cages and kept at constant environmental and nutritional conditions throughout the period of experiment. The animals fed on constant ration and water was supplied ad- labium .

\subsection{Chemicals and antioxidant:}

All chemicals were of analytical grade and obtained from standard commercial suppliers. The antioxidant and chemicals used in the present study were:

2.2.1. Diethylnitrosamine (DEN) and Carbon tetrachloride $(\mathrm{CCl} 4)$ were Purchased from SIGMA Chemical Co. (St. Louis, MO, USA) . Induction of Hepatocarcinogenesis:

Hepatocellular carcinoma was induced in rats by I. P injection of DEN in normal saline (200 $\mathrm{mg} / \mathrm{kg}$ b.wt), 2 weeks later rats received (2 $\mathrm{ml} / \mathrm{kg}$ b.wt) $\mathrm{CCl} 4$ orally at 1:1 dilution in corn oil as a promoter of carcinogenic effect. DEN and $\mathrm{CCl} 4$ administration were repeated once again after 1 month from the first DEN injection. (Hassan et al.,2014).

2.2.2. Moringa olifera was purchased from National Research Centre, Giza, Egypt. Moringa olifera extract powder was dissolved in distilled water and administered orally at a dose level of $500 \mathrm{mg} / \mathrm{kg}$ body weight/day (Bharali et al.,2003).

\subsection{Experimental design:}

After acclimatization to the laboratory conditions, the animals were randomly divided into three groups (15 rats each) placed in individual cages and classified as follow :

Group I: Control Normal group:

Consisted of 15 male rats fed with ordinary diet only without any treatment during the entire experimental period. 
Group II: DEN- induced hepatocarcinogenesis group:

Consisted of 15 male rats received DEN in normal saline (200 mg/ $\mathrm{kg}$ b.wt) by I.P injection, 2 weeks later rats received $(2 \mathrm{ml} / \mathrm{kg}$ b.wt) $\mathrm{CCl} 4$ orally at 1:1 dilution in corn oil as a promoter of carcinogenic effect. DEN and $\mathrm{CCl} 4$ injections were repeated once again after 1 month from first DEN injection.

Group III: DEN + moringa treated group

Consisted of 15 male rats received DEN in normal saline (200 mg/ $\mathrm{kg}$ b.wt) by I.P injection, 2 weeks later rats received $(2 \mathrm{ml} / \mathrm{kg}$ b.wt) CCl4 orally at 1:1 dilution in corn oil as a promoter of carcinogenic effect. DEN and $\mathrm{CCl} 4$ injections were repeated once again after 1 month from first DEN injection then treated orally and daily with $500 \mathrm{mg} / \mathrm{kg}$ body weight of Moringa oleifera in distilled water.

\subsection{Sampling:}

\subsection{1 .Blood samples:}

Twenty-four hours fasting after the last dose of Moringa oleifera administration, rats were anaesthetized under diethyl ether anesthesia. Blood samples were collected by ocular vein puncture in dry, clean tubes and allowed to clot for 30 minutes and serum was separated by centrifugation at 3000 r.p.m for 15 minute. Serum was taken by automatic pipettes and collected in dry sterile tubes, then kept in deep freeze at $-20{ }^{\circ} \mathrm{C}$ until use for subsequent biochemical analysis. All sera were analyzed for determination of the following parameters: AST, ALP, total bilirubin, Albumin, AFP .

2.4.2 .Liver tissue for molecular analysis

Briefly, liver tissues were cut, weighed and minced into small pieces, about $0.5 \mathrm{~g}$ of liver tissues were collected from all animals groups, put in Eppendorf tubes and were immediately kept in liquid nitrogen and stored at $-80^{\circ} \mathrm{C}$ till RNA extraction. The molecular analysis of the relative gene expression in liver tissues evaluated by reverse transcription polymerase chain reaction (RT-PCR) were: (TNF- $\alpha, \mathrm{p} 53$ and Cyp2E1).

\subsection{Analysis:}

\subsubsection{Biochemical analysis}

Serum ALT and ALP activities, total bilirubin, albumin and AFP concentrations were determined according to the method described by Schumann et al., (2002), ELAaser and EL-Merzabani, (1975), Young, (1997) and Doumas et al., (1971) and Engall, (1980), respectively.

\subsubsection{Molecular analysis}

Total RNA was isolated from liver tissue of rats using RNeasy Mini Kit (Thermo Qiagen, \#74104) according to the manufacturer's protocol. Following determination of RNA concentration and purity by Quawell nanodrop Q5000 (USA), $5 \mathrm{mg}$ of total RNA from each sample was reverse transcribed using Quantiscript reverse transcriptase. The produced cDNA was used as a template to determine the relative expression of Tumor necrosis factor alpha (TNF- $\alpha)$, tumor suppressor (P53) and cytochrome P450 2E1 (Cyp2E1) genes using Step One Plus real time PCR system (Applied Biosystem, USA) and gene specific primers. The reference gene, $\beta$ actin, was used to calculate fold change in target genes expression. The thermal cycling conditions, melting curves temperatures, and calculation of relative expression was done. For the treated groups, assessment of 2- $\Delta \Delta \mathrm{Ct}$ determined the fold change in gene expression relative to the control (Livak and Schmittgen, 2001).

Forward and reverse primers sequence for real time PCR.

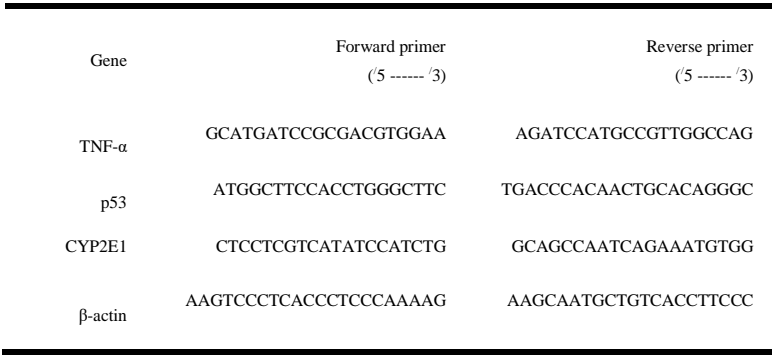

2.6. Statistical analysis: 
The results were expressed as mean $\pm \mathrm{SE}$ using SPSS software program version 16 (SPSS@ Inc., USA). The data were analyzed using one-way ANOVA to determine the statistical significance of differences among groups. Duncan's test was used for making a multiple comparison among the groups for testing the inter-grouping homogeneity. Values were considered statistically significant when $\mathrm{p}<0.05$.

\section{RESULTS}

The obtained results demonstrated in table (1) revealed that, serum ALT and ALP activities, total bilirubin and AFP concentrations were significantly elevated and serum albumin level was significantly decreased in DEN induced liver cancer in rats when compared with the control normal group. Moringa olifera treatment to DEN-induced HCC significantly prevented these changes, resulting in a remarkable protection regarding the same parameters with the ability to restore the value of serum ALT, ALP, total bilirubin, albumin and AFP nearly to the average level of control group when compared with DENinduced HCC group.

The obtained qPCR results presented in table (2) revealed a significant up-regulation of TNF- $\alpha$ gene expression level in liver tissue of DEN-induced liver cancer in rats. This expression was significantly downregulated after treatment with Moringa olifera. However, a significant downregulation of p53 and Cyp2E1 gene expression levels were observed in liver of DEN induced HCC in rats as compared to the normal control group. This expression was significantly upregulated following treatment by Moringa olifera when compared with DEN group.

Table1. Effect of Moringa olifera treatment on serum ALT and ALP activities, total bilirubin, Albumin and AFP concentrations in DEN-induced HCC in rats.

\begin{tabular}{lccccc}
\hline \multicolumn{1}{c}{ Parameters } & ALT (U/L) & ALP(U/L) & T. bilirubin(mg/dl) & Albumin (g/dl) & AFP (ng/dl) \\
Exp. groups & & & & \\
\hline $\begin{array}{l}\text { Group I: } \\
\text { Normal control }\end{array}$ & $190.00 \pm 11.55^{\mathrm{b}, \mathrm{c}}$ & $358.00 \pm 27.14^{\mathrm{b}}$ & $0.58 \pm 0.02^{\mathrm{b}}$ & $3.23 \pm 0.12^{\mathrm{a}}$ & $0.73 \pm 0.007^{\mathrm{c}}$ \\
$\begin{array}{l}\text { Group П: } \\
\text { DEN }\end{array}$ & $365.00 \pm 14.43^{\mathrm{a}}$ & $490.00 \pm 11.55^{\mathrm{a}}$ & $1.75 \pm 0.03^{\mathrm{a}}$ & $1.80 \pm 0.17^{\mathrm{b}}$ & $4.90 \pm 0.47^{\mathrm{a}}$ \\
& & & & & \\
Group III: & $218.67 \pm 12.13^{\mathrm{b}}$ & $402.33 \pm 17.32^{\mathrm{b}}$ & $0.49 \pm 0.09^{\mathrm{b}}$ & $3.17 \pm 0.12^{\mathrm{a}}$ & $3.00 \pm 0.06^{\mathrm{b}}$ \\
DEN+moringa & & & & &
\end{tabular}

Table 2. Effect of Moringa olifera treatment on liver tissue TNF- $\alpha$, p53 and Cyp2E1 gene expression level in DEN induced HCC in rats.

\begin{tabular}{lccc}
\hline \multicolumn{1}{c}{ Parameters } & $\begin{array}{c}\text { TNF- } \alpha \\
\text { Fold change mean } \pm \\
\text { SEM }\end{array}$ & $\begin{array}{c}\text { p53 } \\
\text { Fold change mean } \pm \\
\text { SEM }\end{array}$ & $\begin{array}{c}\text { Cyp2E1 } \\
\text { Fold change mean } \pm \text { SEM }\end{array}$ \\
\hline $\begin{array}{l}\text { Group I: } \\
\text { Normal control }\end{array}$ & $1.00^{\mathrm{d}} \pm 0.09$ & $1.00^{\mathrm{a}} \pm 0.06$ & $1.00^{\mathrm{a}} \pm 0.06$ \\
$\begin{array}{l}\text { Group ח: } \\
\text { DEN group }\end{array}$ & $7.52^{\mathrm{a}} \pm 0.36$ & $0.02^{\mathrm{d}} \pm 0.01$ & $0.05^{\mathrm{c}} \pm 0.005$ \\
$\begin{array}{l}\text { Group III: } \\
\text { DEN +moringa }\end{array}$ & $4.66^{\mathrm{b}} \pm 0.21$ & $0.24^{\mathrm{c}} \pm 0.02$ & $0.23^{\mathrm{b}} \pm 0.02$ \\
\hline
\end{tabular}

Data are presented as (Mean \pm S.E). $\quad$ S.E $=$ Standard error.

Mean values with different superscript letters in the same column are significantly different at $(\mathrm{P} \leq 0.05)$. 


\section{DISCUSSION}

Hepatocellular carcinoma (HCC) is a primary malignancy of the liver and occurs predominantly in patients with underlying chronic liver disease and cirrhosis (Alison, 2005). $N$-Nitrosodiethylamine (DEN) causes a wide range of tumors in all animal species and such compounds are hazardous to human health. The formation of reactive oxygen species (ROS) is apparent during the metabolic biotransformation of DEN resulting in oxidative stress. Oxidative stress leads to carcinogenesis by several mechanisms including DNA, lipid and protein damage, change in intracellular signaling pathways and even changes in gene expression (Balamurugan and Karthikeyan, 2012). Also, DEN is a potent hepatic carcinogen agent (Mahmoud and Abdul-Hamid, 2012). On the other hand, Carbon tetrachloride (CCl4) produced hepatocellular adenomas and carcinomas in rats, mice and hamsters in oral studies and in rats and mice by inhalation exposure (Manibusan, 2010). DEN and $\mathrm{CCl} 4$ is hydroxylated principally by the ethanol inducible CYP2El (cytochrome P450 system) in liver (Verna et al., 1996; Weber et al.,2003).

The obtained results revealed that, serum ALT and ALP activities, total bilirubin and AFP concentrations were significantly elevated and serum albumin level was significantly decreased in DEN/CCl4 induced liver cancer in rats. $\mathrm{DEN}+\mathrm{CCl} 4$ administration induce extensive necrosis and inflammatory infiltration, clusters of hepatocytes, bile duct proliferation and marked atypia (Abd EL- Hamid et al., 2013) or caused hepatic damage by those two toxicants which reflects instability of liver cell metabolism that led to leakage of theses enzymes to circulation. (Hassan et al., 2014). Similarity, Hemieda et al. (2016) showed that treatment with DENA/CCl4 elevate the values of serum ALT, AST and ALP activities and total bilirubin level and markedly decreased serum total proteins and albumin concentrations. Also, Hashem et al. (2016) confirmed that administration of DEN/CCl4 significantly increased liver weight, relative liver weight, AST, ALT and ALP while, body weight, total protein, albumin and $\mathrm{A} / \mathrm{G}$ ratio were markedly decreased. Furthermore, Liver is the main site of DEN metabolism, the generation of ROS in the liver is recognized as an important contributor in DEN-induced damage (Faten et al.,2014). CCl4 is biotransformed by cytochrome P450 (CYP) enzyme system in the endoplasmic reticulum to produce trichloromethyl free radicals $\left(\mathrm{CCl} 3^{\circ}\right)$. Then $\mathrm{CCl}^{\circ}$ leads to elicitation of lipid peroxidation (LPO) and destruction of $\mathrm{Ca}^{2+}$ homeostasis, resulting in cell death (Talib, 2012). Moreover, Borai et al., (2017) displayed that a significant elevation in serum AST, ALT and ALP enzymes activities were observed in DEN-treated group as compared to control normal rats indicating that DEN could induce a damaged effect on liver tissues. The elevation in enzymes activities is due to the rupture in the architecture of cell membrane and the leakage and liberation of enzymes into the serum as a result of carcinogenesis, necrosis and toxicity. Also, ALP indicates alteration in biliary flow. Therefore, during carcinogenesis, these enzymes could be used as biomarkers for HCC response to therapy according to (Tork et al.,2015). Furthermore, Vandenberghe, (1996) reported that hypoalbuminemia may result from liver disorders, which are accompanied by a reduction in albumin synthesis. Albumin is a key component of serum proteins. Also, liver toxicity resulted in decrease serum albumin level (Adams et al.,2005). The results of the present study are in agreement with this finding and demonstrate the decreased functional ability 
of CCl4-injected rat livers (Saravanan et al.,2006).

Meanwhile, treatment with moringa oliefera to DEN/CCL4 induced HCC rats caused a significant decrease in serum ALT and ALP activities, and total bilirubin and increase in albumin level. These results were agreement with Das et al. (2012) who viewed that moringa oliefera reduced the markers of liver injury evaluated by determining the serum activity of ALT, AST and ALP as these enzymes are released secondarily to liver cell damage. Also, Hamza, (2010) stated that the administration of moringa seed extract decreased the CCl4-induced elevation of serum aminotransferase activities and globulin level. Furthermore, Fakurazi et al. (2008) displayed that reduction of the activity of serum ALT, AST and ALP in groups pretreated with moringa olifera extract compared to those treated with acetaminophen alone. Moreover, Balaraba and Muhammad (2012) confirmed that oral pretreatment and co-administration of aqueous extract of moringa oleifera leaves significantly decreased serum ALT, AST and ALP activities, and total bilirubin concentration compared to the normal control. Moringa leaves have been discovered to contain vitamin $\mathrm{E}$ an antioxidant enzyme (Donovan, 2007). Moreover, Moringa contain alkaloids, cinnamates, anthocyanins, quercetin and kaempferol (Siddhuraju and Becker,2003) and proanthocyanidins (Goyal et al.,2007).

Administration of DEN/CCl4 significantly elevated the serum AFP level when compared to normal rats. Similar data was reported by Borai et al. (2017) and Salama et al., (2017) who recognized that AFP concentration was significantly higher in the DEN-treated group as compared to control normal one. It was reported that in DEN induced hepatocarcinogens caused elevation in AFP level (which is widely used as tumor marker for diagnosis of HCC) associated with the increment in tumor growth and progression (Murugan et al.,2015). Similarity, Hashem et al. (2016) reported that a significant increase in AFP level was shown in $\mathrm{DEN}+\mathrm{CCl} 4$ group. The increase in serum AFP concentration has been used as a clinical marker in the diagnosis and monitoring of HCC (Tork et al.,2015). Moreover, Zaazaa et al., (2018) found that an increase in serum AFP level was observed in DEN-induced HCC in rats when compared to control group. Additionally, alpha fetoprotein (AFP) is the most commonly used tumor markers for the diagnosis of hepatocellular carcinoma (HCC) which is a unique immunemodulatory glycoprotein, and normally made by the immature hepatocytes in the fetus (oncofetal). Detection of AFP during monitoring of liver cancer treatment is well accepted in patients with increased AFP level before therapy. It has been recognized that exposure of animals with DEN increases the circulating AFP level (Sadik et al. et al., 2008).

Treatment with moringa to DEN/CCL4 induced $\mathrm{HCC}$ rats caused a significant decrease in serum AFP level when compared with DEN/CCL4 induced HCC group. The results approved by Sadek et al. (2017) who investigated that the decrease in such tumor markers AFP level after moringa oliefera administration, these decline may have been because of abatements in the rate of tumor generation, which phenolic and flavonoid substances are known to be specifically connected to antioxidant activities (Siddhuraju and Becker 2003). The phenolic and flavonoid mixes of moringa oleifera exert their antioxidant activities through scavenging free radicals, restraining enzymatic frameworks and metal chelation (Sadek, 2014).

The obtained qPCR results revealed significant elevation of TNF- $\alpha$ gene expression level in liver tissue of DEN/CCL4 
induced $\mathrm{HCC}$ in rats as compared to the normal control group. Similarity, Kumar et al., (2016) found that TNF- $\alpha$ level significantly increased in DEN treated animals. Also, Habib et al. (2008) demonstrated that elevation of TNF- $\alpha$ gene expression was observed in hepatic tissue of rats with liver cancer induced by ethionine. Moreover, Song et al. (2013) showed that DEN-induced HCC increased TNF- $\alpha$, such tumor necrosis factor alpha (TNF- $\alpha)$ is proinflammatory cytokines produced by macrophages and it plays an important role under tumor conditions (Lutsiak et al., 2005). It has been reported that TNF- $\alpha$ is an essential factor in tumor promotion (Reuter et al.,2011). Moreover, Hamid et al., (2017) stated that $\mathrm{CCl} 4$ elevated proinflammatory cytokines TNF- $\alpha$, IL- 6, COX-2 and NFkB. An increased level of TNF- $\alpha$ was also shown to correlate with hepatic inflammation, necrosis, and hepatic failure (Budhu and Wang, 2006).

Meanwhile, treatment with moringa to DEN/CCL4 induced HCC rats caused a significant downregulated in $\mathrm{TNF}-\alpha$ gene expression and NF- $\kappa \mathrm{B}$ gene expression. The obtained results are noted by Kooltheat et al., (2014) who investigated that moringa depress the expression of RelA, a gene important in $\mathrm{NF}-\kappa \mathrm{B}$ signaling inflammatory reaction. Also, Tan et al. (2015) displayed that moringa downregulated the expression of inflammatory mediators $(\mathrm{NF}-\kappa \mathrm{B}$, iNOS, and COX-2) and pro-inflammatory cytokines (TNF- $\alpha$, IL-1 $\beta$, IL-6, and PGE 2 ). Also, Tan et al. (2015) reported that moringa leaves are enriched with flavonoids such as kaempferol and quercetin (Karthivashan et al.,2013), and also reported the presence of high flavonol contents in Moringa oleifera flowers grown at South Africa (Pakade et al.,2013).

A significant down regulation of $\mathrm{p} 53$ gene expression level was observed in liver tissue of DEN/CCL4 induced HCC in rats as compared to the normal control group. Similarity, Loyden et al., (2017) demonstrated that a significant reduction in p53 gene expression was showed in DEN group administration. The p53 protein acts as a central response to cellular stress or DNA damage by inducing cell cycle arrest, apoptosis, senescence, and other tumorsuppressive actions (Bisteau et al.,2014). Moreover, Khan et al. (2016) stated that decrease in p53 expression induced with $\mathrm{CCl} 4$, which explained that $\mathrm{CCl} 4$ acts as a tumor promoter through increasing the intracellular concentration of ROS necrosis/regeneration and cell proliferation and/or may be due to mutation of p53 led to regarding p53 (Farazi et al., 2006).

$$
\text { Treatment with moringa to }
$$

DEN/CCL4 induced HCC rats caused a significant upregulation in p53 gene expression level when compared with DEN/CCL4 induced HCC group. Similarity, Madi et al. (2016) found that moringa olifera extract treatment resulted in a significant increase in p53 gene expression. Also, Madi et al. (2016) explained that moringa olifera extract treatment resulted in a significant decrease in mitochondrial membrane potential, followed by an increase in ROS, caspase activation, proapoptotic proteins expression (p53, SMAC/Diablo, AIF), and PARP-1 cleavage.

The obtained results revealed significant dysregulation of Cyp2E1 gene expression level in liver tissue of DEN/CCL4 induced HCC in rats as compared to the normal control group. Similarity, Zhang et al., (2013) found that DEN treatment resulted in significant decreases of the activities of CYP2E1, CYP1A2. It has been well documented that DEN-induced hepatocarcinogenesis requires metabolic activation by some forms of CYP450s, especially CYP2E1. Furthermore, Khan et al., (2016) displayed that significant down 
regulation in CYP 2E1 expression was observed in CCl4-induced hepatotoxicity. Who confirmed that reactive oxygen species (ROS) formed during the biotransformation process of $\mathrm{CCl} 4$ are more reactive and toxic than the parental compound. Biotransformation of $\mathrm{CCl} 4$ occurs in the endoplasmic reticulum and the isoenzyme implicated in this process is CYP2E1 (Knockaert et al., 2012). Treatment with moringa to DEN/CCL4 induced HCC rats caused a significant up regulation in Cyp2E1 gene expression when compared with DEN/CCL4 induced HCC group. Various medicinal phytochemical plants caused up regulation in Cyp2E1 gene expression. Resembling Khan et al., (2012) who showed that the active free radical/intermediate of CCl4 caused a reduction in CYP2E1, which was markedly restored by routine treatment.

\section{Conclusion}

The present findings exhibited that moringa olifera improve liver cells damage which caused marked decrease in serum liver marker enzymes (ALT and ALP), total bilirubin and AFP and significantly increased serum albumin concentration. Also, the results of molecular analysis showed significant upregulation of TNF- $\alpha$ and significant downregulation in p53 and CYP2E1 gene expression level in hepatic tissues. These findings suggest the potential ameliorating effect of moringa olifera as an additional powerful natural chemopreventive agent in treatment of hepatocarcinogenesis via initiation of tumor suppressor gene P53 and modifying the metabolic activation of detoxification Enzyme (cytochrome P450 2E1) and palpable anti-inflammatory effect.

\section{REFERENCES}

Abd El-Hamid, N.M.; Abd El-Ghany, M.I.; Nazmy, M.H. and Amgad, S.W. 2013. Can methanolic extract of Nigella sativa seed affect glyco-regulatory enzymes in experimental hepatocellular carcinoma? Enviroment. Health Prev. Med. 18:49-56.

Adams, L.A.; Lymp, J.F.; St Sauver, J.; Sanderson, S.O.; Lindor, K.D.; Feldstein, A. and Angulo, P. 2005.The natural history of nonalcoholic fatty liver disease: a population-based cohort study. Gastroenterology; 129(1):113-21.

Alison, M.R. 2005. Liver stem cells: implications for hepatocarcinogenesis. Stem Cell Rev. 1(3):253-60.

Balamurugan, K., Karthikeyan, J. 2012. Evaluation of Luteolin in the Prevention of N-nitrosodiethylamineinduced Hepatocellular Carcinoma Using Animal Model System. Indian J Clin Biochem.; 27: 157-163.

Balaraba, B.; and Muhammad, W.A. 2012. Prevention of Liver Injury by Moringa oleifera aqueous leaf extract in rats treated with isoniazid and rifampicin. Pharmacognosy Communications. Volume 2 . Issue 3 . Jul-Sep.

Bharali, R.; Tabassum, J. and Azad, M.R.2003. Chemomodulatory Effect of Moringa Oleifera, Lam, on Hepatic Carcinogen Metabolizing Enzymes, Antioxidant Parameters and Skin Papillomagenesis in Mice Asian Pacific J Cancer Prev, 4, 131-139.

Bisteau, X.; Caldez, M.J. and Kaldis, P. 2014. The complex relationship between liver cancer and the cell cycle: a story of multiple regulations. Cancers ; 6(1): 79-111.

Borai, I.H.; Ghanem, H.M.; Ali, M.M.; AbdelHalim, A.H.; Hegazi, A. E.A.; and Mousa, F.M. 2017. Chemopreventive 
Effect of Momordicacharantia Extract Against Chemically Induced Hepatocellular Carcinoma in Experimental Animals. 2017 RJPBCS 8(2) Page No. 529 ISSN: 0975-8585.

Budhu, A., Wang, X.W. 2006. The role of cytokines in hepatocellular carcinoma. J Leukoc Biol.; 80:1197-1213.

Das, N.; Kunal, S.; Ghosh, S.; Bernard, F. and Dey, S. 2012. Moringa oleifera lam leaf extract prevents early liver injury and restores antioxidant status in mice fed with high fat diet. Indian J Exp Biol.; 50(6):404-12.

Donovan, P. 2007. Moringa oleifera: The miracle tree. Natural News. [about $3 p$.$] .$

Dumas, B. T.; Watson, W. A. and Biggs, H. G. 1971. Albumin standards and the measurement of serum albumin with bromcresol green. ClinChimActa. Feb 3;258(1):21-30.

EL-Aaser, A. A. and EL-Merzabani, M. M. 1975. Simultaneous determination of 5'-nucleotidase and alkaline activities in serum. Z. Klin. Chem. Klin. Biochem., 13,453.

Engall, E.1980. Methods in Enzymology, Volume 70, Van Vunakis, H. and Langone, J. J. (eds.), Academic Press, New York, 419-492.

Fakurazi, S.; Hairuszah, I. and Nanthini, U. 2008. "Moringa oleifera Lam prevents acetaminophen induced liver injury through restoration of glutathione level," Food and Chemical Toxicology, vol. 46, pp. 2611-2615.

Farazi, P.A.; Zeisberg, M.; Glickman, J.; Zhang, Y.; Kalluri, R. and DePinh, R.A. 2006. Chronic bile duct injury associated with fibrotic matrix micro environment provokes cholangiocarcinoma in p53-deficient mice. Nutri. ;6:6622-6627.

Gold, S.L.; Ames, N.B. and Slone,H.T. 2002. Misconceptions about the causes of cancer. D. Paustenbach, ed., 14151460 .

Goyal, B.R.; Agarwal, B.B.; Goyal, R.K. and Mehta, A.A. 2007. Phytopharmacology of Moringa oleifera Lam. An overview. Natural Product Radiance.; 6(4):347-353.

Habib, S.H.M.; Makpol, S.; Hamid, N.A.A.; Das, S.; Ngah, W.Z.W. and Yusof, Y.A.M. 2008. Ginger extract (zingiberofficinale) has anti-cancer and anti-inflammatory effects on ethionineinduced hepatoma rats. Clinics.;63:807-13.

Hamid, M.; Liu, D.; Abdulrahim, Y.; Liu, Y.; Qian, G.; Khan, A.; Gan, F. and Huang, K. 2017. Amelioration of CCl4-induced liver injury in rats by selenizing Astragalus polysaccharides: Role of proinflammatory cytokines, oxidative stress and hepatic stellate cells. Res Vet Sci. Oct;114:202-211.

Hamza, A.A. 2010. Ameliorative effects of moringa oleifera lam seed extract on liver fibrosis in rats, food chemtoxicol ,48.345.

Hashem, A.S.;Taha, N.M.; Mandour,A.A.; Lebda, M.A.; Balbaa, M.E.; and ElMorshedy, A.S. 2016. Hepatoprotective Effect of Silymarin and Propolis in Chemically Induced Chronic Liver Injury in Rats: Alexandria J Vet Sci, Apr. 49 (1): 35-43.

Hassan, S.K.; Mousa, A.M.; Eshak, M.G.; Farrag, A.R.H. and Badawi, A.F.M. 
2014. Therapeutic and chemopreventive effect of nanocurcumin against diethyl nitrosamine induced hepatocellular carcinoma in rats. Int. J. Pharmcol. Pharmceuit. Sci. 6(3): 54-62.

Hemieda,F.A.E.; Serag,H.M.; El-Baz, E. and Ramadan, S.M.E. 2016. Therapeutic efficacy oflicorice and/or cisplatin against diethylnitrosamine and carbon tetrachloride-induced hepatocellular carcinoma in rats. J Am Sci;12(1):1019].

Karthivashan, G.; Tangestani-Fard, M.; Arulselvan, P.; Abas, F. and Fakurazi, S. 2013. Identification of bioactive candidate compounds responsible for oxidative challenge from hydroethanolic extract of moringa oleifera leaves. Journal of Food Science, vol. 78, no. 9, pp. C1368-C1375.

Khan, R.A.; Khan, M.R. and Sahreen, S. 2012. CCl4-induced hepatotoxicity: protective effect of rutin on p53, CYP2E1 and the antioxidative status in rat. BMC Complementary and Alternative Medicine 12:178.

Khan, R.A.; Khan, M.R.; Sahreen, S. and Alkreathy, H.M. 2016. Effect of Launaea procumbens extract on oxidative marker, p53, and CYP 2E1: a randomized control study. Food \& Nutrition Research [03 Mar, 60:29790.

Knockaert, L.; Berson, A.; Ribault, C.; Prost, P.E.; Fautrel, A.; Pajaud, J.; Lepage, S.; Lucas-Clerc, C.; Bégué, J.M.; Fromenty, B. and Robin, M. A. 2011. Carbon tetrachloride-mediated lipid peroxidation induces early mitochondrial alterations in mouse liver. Lab Invest. Mar;92(3):396-410.
Kooltheat, N.; Sranujit, R.P.; Chumark, P.; Potup, P.; Laytragoon-Lewin, N. and Usuwanthim, K. 2014.An Ethyl Acetate Fraction of Moringa oleifera Lam. Inhibits Human Macrophage Cytokine Production Induced by Cigarette Smoke: Nutrients; 6(2): 697-710.

Kumar, R.S.; Kumar, S.V.; Balasubramanian, R; Narayanaperumal, P. and Dharmasivam, $\quad$ M. 2016. Chemopreventive effect of Indigo feralinnaei extract against diethylnitrosamine induced hepatocarcinogenesis in rats. Journal of Applied Pharmaceutical Science 6 (11); 199-209.

Kung, C.J.; Curri, S.I.; Forbes, J.S.; James, A. and Ross, A.J. 2010. Liver development, regeneration, and carcinogenesis. Journal of biomedicine and biotechnology., 6(10):1-8.

Livak, K.J. and Schmittgen, T.D. 2001. Analysis of relative gene expression data using real-time quantitative PCR and the $2(-\Delta \Delta \mathrm{Ct})$ method. Methods. ;25:402408.

Loyden, G. V., Martínez, L.P.; Gómez, S.V.; Carreón, J.I.P. and de Sánchez, V.C. 2017. Cancer chemoprevention by an adenosine derivative in a model of cirrhosis-hepatocellular carcinoma induced by diethylnitrosamine in rats. Tumor Biol.;39(2):1010428317691190.

Lutsiak, M.E.; Semnani, R.T.; De Pascalis, R.; Kashmiri, S.V.; Schlom, J. and Sabzevari, H. 2005. Inhibition of $\mathrm{CD} 4+25+\mathrm{T}$ regulatory cell function implicated in enhanced immune response by low-dose cyclophosphamide. Blood 105: 2862-2868. 
Madi, N.; Dany, M.; Abdoun, S. and Usta J. 2016. "Moringa oleifera's Nutritious Aqueous Leaf Extract Has Anticancerous Effects by Compromising Mitochondrial Viability in an ROS-Dependent Manner," Journal of the American College of Nutrition, vol. 35, no. 7, pp. 604-613.

Mahmoud, M.S. and Abdul-Hamid, M. 2012. Green tea extract ameliorates Liver and pituitary gland toxicity induced by diethylnitrosamine in male rats. $\mathrm{J}$ Am Sci., 8(3): 58-71.

Manibusan, M.; Jinot, J.; Kopylev, L.; White, P.; Schlosser, P. and Park, T. 2010. Toxicological review of carbontetrachloride. EPA., (56-23 5):1-473.

Mukherjee, B.; Ghos, K.M. and Chowdhury, H.M. 2009. Chemically induced hepatocellular carcinoma and stages of development with biochemical and genetic modulation: a Special reference to insulin-like growth factor II and Raf gene signaling. ICMR.,(58):201-219.

Murugan, S.; Ameesh, M.N.; Shilpa, S.; Vishal, B. 2015. Study on the Anticarcinogenic Efficacy of Withaferin-A in DEN Induced Hepatocellular Carcinoma: Morphology and Histopathology. IJHSR .273 Vol.5; Issue: 9; September.

Pakade, V.; Cukrowska, E. and Chimuka, L. 2013. "Metal and flavonol contents of Moringa oleifera grown in South Africa," South African Journal of Science, vol. 109, no. 3-4, pp. 1-7,.

Provincial, F. 2010. Guidelines for canadian drinking water quality: guideline technical document - carbon tetrachloride. ISBN.,2-5.

Reuter, S.; Gupta, S.; Park, B.; Goel, A. and Aggarwal, B. B. 2011. Epigenetic changes induced by curcumin and other natural compounds. Genes Nutr, 6, 93-108.

Sadek, K.M. 2014. Chemotherapeutic efficacy of an ethanolic Moringa oleifera leaf extract against chromium-induced testicular toxicity in rats. Andrologia. 46:1047-1054.

Sadek, K.M.; Abouzed, T.K.; Abouelkhair, R. and Nasr, S. 2017. The chemoprophylactic efficacy of an ethanol Moringa oleifera leaf extract against hepatocellular carcinoma in rats, Pharmaceutical Biology, 55:1, 14581466.

Sadik, N.A.H.; EL-Maraghy, S.A. and Ismail, M. F. 2008. Diethylnitrosamineinduced hepatocarcinogenesis in rats: possible chemoprevention by blueberries: Afr. J. Biochem. Res. Vol.2 (3), pp. 081-087, March.

Salama, A.F.; Abdel-Hamid, N. M.; Elsheekh, M.; Tosson, E. and Gabr, A. M.2017. Spirulina Platensis Microalgae Protects against Diethyl Nitrosamine Carcinogenic Effect on Female Albino Rats. AJVS. Vol. 53(1): 167-179. April.

Satir, A.A. 2007. An update on the pathogenesis and pathology of hepatocellular carcinoma. Bahrain Medical Bulletin., 29(2):1-7.

Schumann, G.; Bonora, R.; Ceriotti, F.; Férard, G.; Ferrero, C.A.; Franck, P.F.H.; Gella, F.J.; Hoelzel, W.; Jørgensen, P.J.; Kanno, T.; Kessner, A.; Klauke, R.; Kristiansen, N.; Lessinger, 
J.M.; Linsinger, T.P.; Misaki, H.; Panteghini, M.;Pauwels, J.; Schiele, F.; Schimmel, H.G.; Weidemann, G. and Siekmann, L. 2002. IFCC primary reference procedures for the measurement of catalytic activity concentrations of enzymes at $37{ }^{\circ} \mathrm{C}$ : Part 5. Reference procedure for the measurement of catalytic concentration of aspartate-aminotransferase. Clin. Chem. Lab Med. ;40:725-733.

Siddhuraju, P. and Becker, K. 2003. Antioxidant properties of various solvent extracts of total phenolic constituents of 3 differrent agroclimatic origins of drumstick tree (Moringaoleifera) leaves. J. Agric. Food Chem.; 51(8):2144-2155.

Smolin, L.A. and Grosvenor, M.B. 2007. Nutrition science and applications. New York: John Wiley \& Sons Inc.

Song, Y.; Jin, S.J.; Cui, L.H.; Ji, X.J. and Yang. 2013. Immunomodulatory Effect of Stichopus japonicus acid Mucopolysaccharide on experimental hepatocellular carcinoma in rats. Molecule. 18(4):7179-7193.

Sreelatha, S, Padma, P.R. 2010. Antioxidant activity and total phenolic content of Moringa oleifera leaves in two stages of maturity. Plant Foods Hum Nutr. 64:303-311

Tan, W.S.; Arulselvan, P.; Karthivashan, G.; and Fakurazi， S. 2015. Moringa oleifera Flower Extract Suppresses the Activation of Inflammatory Mediators in Lipopolysaccharide-Stimulated RAW 264.7 Macrophages via NF- $\kappa B$ Pathway Mediators of Inflammation. Volume, Article ID 720171, 11 pages.
Talib, H. 2012. Ph. D Thesis, FOP, IU, Lucknow.

Tork, O.M.; Khaleel, E.F. and Abdelmaqsoud, O.M. 2015. Altered Cell to Cell Communication, Autophagy and Mitochondrial Dysfunction in a Model of Hepatocellular Carcinoma: Potential Protective Effects of Curcumin and Stem Cell Therapy. APJCP.16.18.8271.

Vandenberghe, J. 1996. Hepatotoxicology: Structure, function and toxicological pathology. In Toxicology: Principles and Applications Edited by Niesink, JM, Vries J, Hollinger MA Vries J, Hollinger MA, 669-721.

Verna, L.; Whysner, J. and Williams, G.M. 1996. N-nitrosodiethylamine mechanistic data and risk assessment: bioactivation, DNA-adduct formation, mutagenicity, and tumor initiation. PharmacolTher ; 71: 57-81.

Weber, L. W.; Boll, M. and Stampfl, A. 2003. Hepatotoxicity and mechanism of action of haloalkanes: Carbon tetrachloride as a toxicological model. Crit. Rev. Toxicol., , 33, 105-136.

Young D.S. 1997. Effects of Preanalytical Variables on Clinical Laboratory Tests, 2nd ed. Washington, DC: AACC Press;3-85.

Zaazaa, A.M.; Lokman, M.S.; Shalby, A.B.; Ahmed, H.H. and El-Toumy, S.A. 2018. Ellagic Acid Holds Promise Against Hepatocellular Carcinoma in an Experimental Model: Mechanisms of Action. APJCP.19.2.387.

Zhang, C.L.; Zeng, T.; Zhao, X.L. and Xie, K.Q. 2013. Garlic Oil Attenuated Nitrosodiethylamine-Induced Hepatocarcinogenesis by Modulating the Metabolic Activation and 
Hussein et al. (2018). BVMJ-35(2): 638-649

Detoxification Enzymes. Int $\mathrm{J}$ Biol Sci ; 9(3):237-245. 